\title{
Course Design for Teaching Development: Key Considerations for Faculty Developers
}

Mohammed Saleh Alkathiri, Assistant Professor of Teaching and Learning with emphasis in Higher Education, Deanship of Academic Development, Imam Abdulrahman bin Faisal University, Dammam, Saudi Arabia. Email: msalkathiri@iau.edu.sa

\begin{abstract}
The purpose of this paper is to address key elements of designing a course that aims at developing core competencies in teaching and learning for faculty members. The paper includes discussion of the initial preparation, objectives and learning outcomes, syllabus construction, assignments, assessments, grading, and teaching strategies. The paper is divided into sections, one for each theme or key topic in relation to course design. Finally, a brief reflection concludes the paper. The process of course design did not only allow to learn about the principles of course design, but also expanded one's understanding of oneself as a faculty developer.
\end{abstract}

Key words: course design, syllabus, faculty development, teaching and learning, higher education

\section{Introduction}

The ability to teach is one of the attributes for successful professors (Alkathiri \& Olson, 2018). Therefore, many scholars have called for taking actions to improve faculty members' teaching competencies (Alkathiri, 2018). Faculty members tend to engage in formal and informal development opportunities to learn about how to teach in higher education (Alkathiri \& Olson, 2018, 2019). Faculty development programs are well-recognised formal methods in which faculty members learn and develop their teaching skills (Alkathiri \& Olson, 2018, 2019). However, literature seldom includes discussion on the topic of faculty developer's own practice and details of designing courses that focus on developing faculty member teaching competencies.

Designing a new course can be challenging because there are important decisions that must be made early in the process. Faculty developers must consider "three crucial decisions: what to teach, how to teach it, and how to ensure that students are learning what is being taught" (Davis, 
2009 , p. 3). Having a general idea of the course is not enough to start putting materials together. Faculty developers need to know which topics should be included, the best teaching strategies for a specific course, the type of learner body that would be taking the course, and the way in which learners (i.e., faculty members) would be likely to learn best.

In this paper, the author shares a reflective account of practice and discusses his own planning and design of a course entitled "Developing Core Competencies in Teaching and Learning." The current study of course design was derived from the author's experience as a faculty developer at the Deanship of Academic Development, Imam Abdulrahman bin Faisal University, Dammam, Saudi Arabia. A major part of his job includes the preparation, review and execution of professional development training programs for faculty members on various topics of teaching and learning. This paper provides insights and recommendation for faculty developers interested in designing courses and training programs with the intention of developing faculty members' teaching and learning core competencies in higher education.

\section{Preparatory Work}

Before listing the topics that are important to address in the course, the faculty developer has to identify the teaching constraints (Wall, 2013) such as the major and teaching experience of faculty members taking the course, the requirements of prerequisite courses, and the available number of instruction hours (Davis, 2009). Considering these constraints, the current course was for learners who are looking to teach in higher education (most likely master's and doctoral students), as well as for current faculty members (especially within non-educational disciplines) who wish to become more effective and competent in teaching and learning in higher education. The purpose of the course is to assist learners in acquiring the knowledge and skills necessary for teaching in higher education, as well as to set the foundation for the study of more advanced courses. Therefore, no prerequisite courses will be required to take this course. Also, the course will be developed with three hours available for instruction per week.

One important strategy to prepare for the design of a new course is to talk with faculty developers who have previously taught similar courses. Davis (2009) suggested that the course designer should ask his or her colleagues for their syllabi and assignment samples. Reviewing the syllabi, textbooks, and handouts from similar courses gave a sense of the topics that should be included in this new course. According to Davis (2009), it is important to investigate the difficulties that learners and faculty experienced in similar courses. An excellent way to learn about the strengths and weaknesses of a course is to review past course evaluations (Davis, 2009). In this case, the author did not have learner evaluations for similar courses. However, he had access to results of a needs' assessment concerning the topics where faculty members needed training. Although the needs' assessment was conducted at his university, faculty members were from different backgrounds and nationalities. Therefore, the results used for 
the purpose of choosing topics reflect the need of a wide range of faculty members in regard to teaching and learning competencies.

It is important to notice that addressing every topic that could be important to learn about would have resulted in having too many topics. When the topics are not manageable, they can negatively affect learning (Wall, 2013). Davis (2009) suggested that in order to reduce the number of topics, one should identify essential and optional concepts by dividing topics into three groups that include "basic material should be mastered by every student, recommended material should be mastered by every student seeking a good knowledge of the subject, and optional material should be mastered by those students with special interests and aptitudes" (p. 8). This strategy helped rank the topics based on their significance to the type of learners who would be taking the course. Through the topic choosing process, the author came to the conclusion that the course should focus on key concepts of teaching and learning such as enhancing learning, lesson design, learning outcomes, instructional strategies, educational technology, assessment, and teaching evaluation.

\section{Conceptual Framework}

Learning is a complex process; it is not only a change in behaviour, but also an experience of a potential to change (Merriam, Caffarella, \& Baumgartner, 2007). "Learning is a process that brings together cognitive, emotional, and environmental influences and experiences for acquiring, enhancing, or making changes in one's knowledge, skills, values, and worldviews" (Merriam et al., 2007, p. 277). For the purpose of designing the current course, the Academic Development Conceptual Framework illustrated in Figure 1 was used as a guideline to address the four faculty development areas in relation to teaching including values, knowledge, practice, and community of learners. One theory that explains learning as a meaning-making process is the constructivist theory. The constructivist view sees learning as an active process where learners co-construct new ideas through social interactions based upon their current and past experiences (Kumar \& Refaei, 2013; Merriam et al., 2007).

It is essential in course design to establish a conceptual framework for teaching a course (Davis, 2009). A conceptual framework will not only allow the faculty developer to consider his or her teaching situation more carefully, but also will assist learning. According to Davis (2009), "students need to understand why you have arranged topics in a given order and the logic of the themes or concepts you have selected" (p. 24). The constructivist instruction will be utilised to address different learning styles and meet learner needs. 


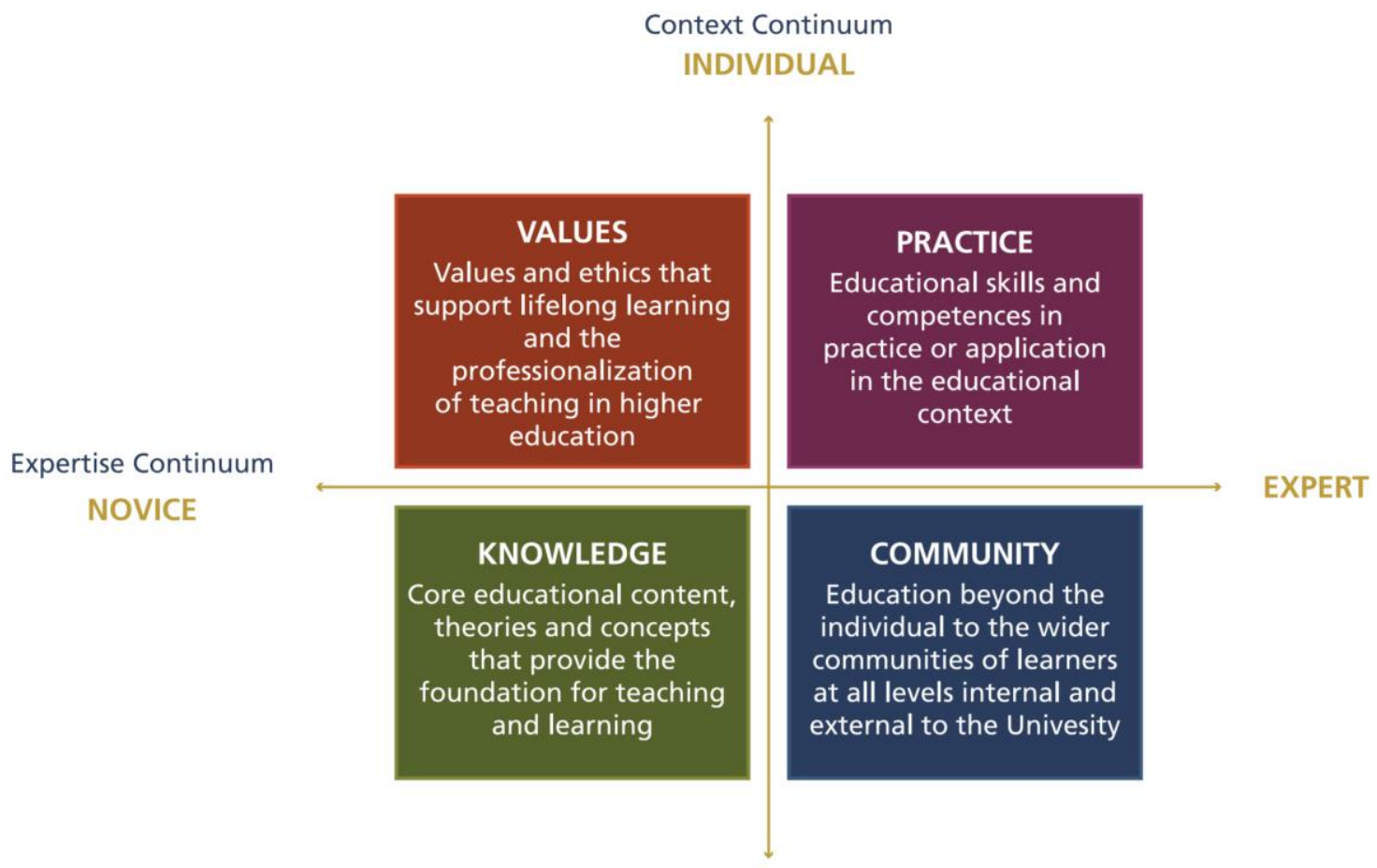

COMMUNITY

Figure 1. Academic Development Conceptual Framework (Deanship of Academic Development, 2019)

According to Merriam et al. (2007), "the process of learning which is centered on learner need, is seen as more important than the content; therefore, when educators are involved in the learning process, their most important role is to act as facilitators, or guides" (p. 284). Based on the conceptual framework, the role of the faculty developer is to facilitate learning. Learners will be given opportunities to communicate their experiences, reflect on their understanding, and share their thoughts with each other.

\section{Course Objectives and Learning Outcomes}

After refining a list of topics for the course and considering the teaching approach through the conceptual framework, the faculty developer can draft course objectives and learning outcomes. According to Davis (2009), writing objectives helps the course designer plan the course and specify what he or she wants to do. Because the teaching approach is learnercentred conforming to the conceptual framework, the faculty developer can work on course objectives, learning outcomes, and assessments simultaneously (Wall, 2013). Considering the assessments for the course is important for determining the measurement systems for learner achievement of course objectives. According to Huba and Freed (2000), "focusing on student learning requires that we specify the goals or intended outcomes of the experiences students 
have at our institutions" (p. 92). The objectives statements reveal that the faculty developer is intentional about promoting learning, and underline the specific ways the course will enable learners to achieve the intended learning outcomes (Huba \& Freed, 2000).

It is important to understand the difference between course objectives and learning outcomes. Course objectives are statements that describe what the faculty developer expects students to learn by the end of the course, but the learning outcomes describe how students will demonstrate what they actually learned (Huba \& Freed, 2000). Furthermore, each of the learning outcomes should be learner-centred by focusing on the student role of learning instead of focusing on the faculty developer's role of instruction (Huba \& Freed, 2000).

Through the process of establishing objectives and outcomes, the faculty developer should take into consideration the amount of training time available, the learner workload and their abilities to achieve the intended learning outcomes, and high order thinking skills that are essential to learn in this course (Davis, 2009; Huba \& Freed, 2000). As a result, course objectives and learning outcomes are learner-centred, specific, clear, and concise.

An important purpose of the learning outcomes is to build a learner-centred course that promotes clear and achievable expectations while enhancing learning experiences (Huba \& Freed, 2000). Each of the outcomes statements focuses on what learners will be able to do. For example, one learning outcome states that "learners will be able to explain their roles as effective educators through large and small group discussion, and written reflections on their teaching experiences and characteristics of good teaching." In this example, the statement explains that learners will be participating in large and small group discussions, as well as writing reflections to demonstrate their understanding of the role of effective educators. This learning outcome enhances student learning experiences while it can be achieved throughout the semester.

Each of the learning outcomes describes a specific verb that learners will be able to do after the instructions. For example, action verbs (i.e., explain and describe) that can be observed and measured are used to state what learners are expected to be able to do by the end of this course (Davis, 2009; Huba \& Freed, 2000; Scouller, 1998). Further, learner-centred outcomes should "focus on skills and abilities central to the discipline and based on professional standards of excellence" (Huba \& Freed, 2000, p. 98). Throughout this course, learners should be able to describe the role of the educator and the role of the learner based on learning theories' principles through small group activities.

The learning outcomes should focus on promoting higher-order thinking skills such as critical thinking and problem solving through discussion, analysis and application (Davis, 2009; Kumar \& Refaei, 2013; Maki, 2010). The strategic use of the course content will increase quality learning (Bain, 2004; Scouller, 1998). In this course, one of the learning outcomes is 
that "learners will be able to evaluate key elements for effective lesson planning by writing an analysis of their own lesson plans or their peers' lesson plans." This is a good example of the integration of intellectual skills (e.g., critical, analytical, synthesising and problem-solving skills) through the learning outcomes. Furthermore, the learning outcomes allow participants to realise the way in which they will learn, and how they will demonstrate what they have learned (Kumar \& Refaei, 2013; Maki, 2010).

\section{Preparing Syllabus}

Preparing a comprehensive syllabus gives learners "an immediate sense of what the course will be about, what they will learn, and how their academic progress will be evaluated" (Davis, 2009, p. 21). Preparing a syllabus also helps in deciding which topics should be covered and at what pace (Davis, 2009). Furthermore, well-prepared syllabi show participants that the faculty developer is taking his or her teaching seriously (Davis, 2009). For the current course, the author followed Davis' (2009) suggestions regarding a standard syllabus. The syllabus includes general information about the course (e.g. the course title, the class time and location); information about the faculty developer (e.g. name, department, office address, and e-mail address); a description of the course and prerequisites; an overview of the course purpose; course objectives and learning outcomes; the conceptual framework; the activities of the course (e.g., discussion sections and small group work); the course assigned textbook; a list of the assignments, assigned readings and activities by date and topic; information of the accommodations for learners with special needs; and information on grading procedures and course policies (Davis, 2009, pp. 22-27). Also, the learning outcomes were included in the course syllabus. Sharing the learning outcomes in course syllabi helps learners reflect on how well they are achieving the learning outcomes (Huba \& Freed, 2000). Further, learner misunderstandings about the due dates of assignments and grading criteria can be minimised through the use of the syllabus (Davis, 2009).

\section{Assignments}

According to Bain (2004), "many examinations may capture the students' ability to take certain kinds of tests, but reflect little about the way students think" (p. 151). The assignments in this course are the opposite to those types of examinations mentioned by Bain. Assignments in this course will facilitate learning by accommodating for opportunities to share learner experiences, demonstrate their understanding, and to build new experiences. A variety of assignments will be used, such as individual reading, group discussion, small group activities, reflective writing, portfolios, and presentations. The variety of assignments will give opportunities for learners to complete tasks in different ways (Huba \& Freed, 2000). Assignments are designed to assist learners in the development of their critical thinking, problem solving, and self-analysis (Davis, 2009; Huba \& Freed, 2000; Kumar \& Refaei, 2013). 
According to Huba and Freed (2000), a valid assignment "yields useful information to guide learning" (p. 225). Therefore, a description of each assignment, and the standards for performance in each, are clearly stated in the syllabus. This will help learners understand how an assignment assists their learning while also making clear the faculty developer's expectations regarding learner performance (Davis, 2009; Huba \& Freed, 2000). Participants will be required to complete a total of six assignments. Although the number of assignments may sound overwhelming, most of them are short assignments that can be managed and completed within a reasonable amount of time. Therefore, being conscious of the learner's workload when designing and developing the course assignments is fundamental.

The first assignment is participation that includes attendance of all course meetings, completion of assigned reading, and active involvement in class discussion and activities. Participants are expected to take responsibility for their learning. Participants learn best when they take an active role in their learning process (Alkathiri, 2019; Davis, 2009; Frisby \& Martin, 2010; Merriam et al., 2007). For example, learners who take part in small group activities are more likely to understand the course material than other learners who remain passive during course session (Dancer \& Kamvounias, 2005; Frisby \& Martin, 2010). Dancer and Kamvounias (2005, p. 448) suggested five criteria for active participation: preparation for course session, contribution to discussion, group skills, communication skills, and attendance. Active involvement is essential in order to meet the goal of building peer support. It also is necessary for the collaboration of sharing ideas with others (Frisby et al., 2014; Rocca, 2010). Encouraging participants to have an active role in class by bringing in their own personal experiences will help make each lesson more meaningful (Davis, 2009; Frisby et al., 2014; Rocca, 2010).

The second assignment is Thinking about Good Teaching (including Teaching Experience Summary and Teaching Philosophy Statement). The assignment is meant to encourage participants to reflect on their experiences as faculty members, and to think critically about what makes a good teacher. An important goal of higher education is to help learners become more reflective thinkers (Huba \& Freed, 2000). Also, this assignment will assist participants in considering their roles as current or future faculty members in higher education.

Because this course is not an advanced one, it will only be focusing on the characteristics of a good teacher. The purpose of the assignment is to help learners to demonstrate their understanding of "good teaching" in higher education. Participants will be encouraged to develop an understanding of their role in light of the characteristics of a good teacher. For example, when learners understand that good teachers are student-centred, they will understand that their role in teaching is to empower students through facilitating learning (Houser \& Frymier, 2009). Also, good teachers care about ongoing learning rather than grading; therefore, the participant's own teaching philosophy should encourage and support lifelong learning. 
The third assignment is to write a brief summary of one pre-assigned adult learning theory. Participants will explain the concept of the theory as it involves the role of the educator and the role of the learner. When the assignment is complete, participants will share their summaries with others in groups (each group will include at participants representing different learning theories). Davis (2009) asserted the importance of including relevant and real-world activities in courses. This assignment will expose learners to four learning theories, and urge them to think about the implications of such theories in the classroom.

The fourth assignment is to create and analyse a lesson plan for a topic from the participant's discipline, or field of study, that can be taught in an undergraduate level course. Participants are required to specify the learning objectives and outcomes, lesson materials, lesson procedures, and the assessment plan (i.e., formative and summative assessment). Through the completion of this hands-on assignment, participants will be able to demonstrate their understanding of learning outcomes, instructional strategies, and assessment methods. "Hands-on activities or fieldwork provide a bridge between abstract and concrete learning, and they can help students develop a more complex approach to learning" (Davis, 2009, p. 261). Further, the assignment will assist participants in the evaluation of key elements for effective lesson planning by writing an analysis of their own lesson plans or their peers' lesson plans.

The fifth assignment required in the course is a hands-on project. Participants will have five options for their projects: writing a summary of their own learning development, conducting an interview with an educator and then writing a summary of the interview, writing a book review that relates to the course, writing a literature review that relates to the course, or other appropriate work that relates to the course. The purpose of the project assignment is to demonstrate an integration of knowledge and practice of teaching and learning, as well as to "help students develop a more complex approach to learning" (Davis, 2009, p. 261). Also, the assignment offers multiple options for participants to complete their projects in various ways (Huba \& Freed, 2000).

Participants will make short presentations (i.e., 15-20 minutes) including an overview of their projects. They will cover the important aspects of the project, explain what they have learned, and answer their peers' questions. This assignment will provide an opportunity for participants to share their work and learn from each other.

The sixth and last assignment is the creation of a teaching portfolio. This assignment will be completed by participants as they develop their knowledge throughout the course, and it may be kept by participants throughout their career in higher education. According to Huba and Freed (2000), "the purpose of portfolio assessment is to help the learners become integral and conscious participants in their learning processes" (p. 233). The portfolio will include a table of contents, a brief written explanation of the importance of each item in the portfolio, previous assignments (i.e., teaching experience summary; summaries of adult learning theories; teaching 
philosophy statement; lesson plan and lesson plan analysis; and the participant's project), and other helpful resources (e.g., hand-outs, pictures, notes, articles, a list of book titles, or any other resources). This type of portfolio is all-inclusive. Learners keep a full record of their work during the course, and eventually provide an explanation of its importance (Huba \& Freed, 2000, p. 235). Furthermore, the assignment will allow the faculty developer to examine the participant learning process from the learner's point of view (Huba \& Freed, 2000).

Outcome-based assignments emphasise what learners should be able to know, understand, and do as a result of the course (Maki, 2010). Coherent assignments should be well-structured and lead to the intended learning outcomes (Huba \& Freed, 2000). Also, assignments should be structured rigorously so that learners can understand course content and use it effectively (Huba $\&$ Freed, 2000, p. 225). The assignments that were developed for this course are learnercentred, outcome-based, engaging, coherent, and rigorous. Learners will be offered different tasks that address the intended learning outcomes. Also, learners will be given opportunities to demonstrate their understanding through the creation of products (i.e., lesson plans, portfolios, and presentations). Learner-centred assignments help participants learn the declarative knowledge (i.e., the facts and concepts of the course), as well as the procedural or metacognitive knowledge (i.e., critical thinking, and problem solving) (Huba \& Freed, 2000).

\section{Assessment}

Assessment is critical for the improvement of higher education (Bresciani, 2006; Huba \& Freed, 2000; Maki, 2010). According to Maki (2010), "assessment becomes an opportunity to explore the efficacy of pedagogy, instructional design, use of current and emerging technologies, and other educational experiences" (p. 6). The goal of assessment is to reflect on participant learning in order to "determine over time who learns what, when, where, why, how, and how well" (Maki, 2010, p.1). In order to develop an assessment plan for the new course, major elements for an effective assessment plan were considered as suggested by Bresciani (2006). To assure quality outcomes in the course, the assessment plan should include the following: course name and description, learning outcomes, an assessment method for each outcome, the subject and assignment being evaluated, results by outcome, and an interpretation of the results (Bresciani, 2006). Failure to implement outcomes-based assessments will result in weak outcomes (Huba \& Freed, 2000). Learner-centred assessment is more focused on the participant's role (learning) rather than the faculty developer's role (teaching or grading) (Huba $\&$ Freed, 2000). "As faculty members, we must decide on the intended learning outcomes of the curriculum and the measures that are used to assess them" (Bresciani, 2006, p. 76). Furthermore, direct and indirect methods of assessment will be used to validate participant learning in different ways. Using direct and indirect methods to assess learner outcomes provides more information on the quality of learning (Maki, 2010). Collecting and using feedback from participants is important in order to identify learning difficulties, to improve learning, and to inform instructions (Bain, 2004; Huba \& Freed, 2000). 
The purpose of the assessment plan is to ensure that participants achieve the learning objectives, as well as to get feedback on facilitation and teaching methods (Davis, 2009; Huba $\&$ Freed, 2000). The assessment plan for the current course will utilise various types of assessment, such as pre-assessment, formative assessment, and summative assessment. Multiple methods of assessment evaluate participant learning more accurately (Maki, 2010).

The faculty developer uses pre-assessment (e.g., opening questions) to explore previous knowledge about the topic being taught. It also sets the mode for the topic being presented, and identifies what specific topics are of most interest to the participants (Davis, 2009). In addition, through the second assignment (i.e., Teaching Experience Summary and Teaching Philosophy Statement), the faculty developer will be able to pre-assess and recognise the diverse backgrounds and personal interests of learners.

The formative assessment (i.e., observation of in-class group activities and discussion and review of reflection papers) will measure participant progress while learning is taking place (Davis, 2009; Huba \& Freed, 2000). In this course, the participation assignment will be used as a formative assessment, where the faculty developer will be able to observe and evaluate learner progress. For example, the faculty developer will be able to address the areas in which learners need further assistance based on their frequently asked questions. The faculty developer also may focus on a participant or a group of participants who show signs of struggle to keep up with the rest of learners. The third assignment (writing a brief summary of an adult learning theory) will also be used as a formative assessment. This assignment will assess the participants' overall understanding of the role of educator and the role of learner, before getting to more advanced lessons on the roles of students and teachers. In addition, the formative assessment will be used to assess the teaching strategies being used (Davis, 2009; Huba \& Freed, 2000). For example, if the faculty developer noticed that participants were more active and preferred to work in large groups, he or she would often offer large group discussions rather than small group activities. The sixth assignment (teaching portfolio) is considered formative assessments as it allows learners to examine their growth and accomplishment over the semester (Davis, 2009, p. 369). Furthermore, the portfolio assignment will allow the faculty developer to examine the participant learning process from the learner's point of view (Huba \& Freed, 2000).

The summative assessment takes place after the learning has been completed in order to determine to what extent participants have learned (Davis, 2009; Huba \& Freed, 2000). The fourth assignment, that to create and analyse a lesson plan, is both a formative and summative assessment. The completion of the lesson plan will be the formative assessment of participant learning about the topic of lesson plan development. Further, the completion of the lesson plan analysis will be the summative assessment to find out to what extent participants have learned about the topic. The project assignment is one of the summative assessments in the course. By 
the time participants begin working on this assignment, they should be able to show advanced levels of understanding and integration of course material.

A rubric with a set of standards will be used for assessment (see the Grading section for further discussion of grading methods and rubrics). As part of the assessment plan, some techniques for collecting feedback from participants will be used (such as the minute paper, muddiest point, and one-sentence summary) (Huba \& Freed, 2000). The purpose of using these techniques is "to involve and engage [participants] in providing data that can help improve teaching and learning" (Huba \& Freed, 2000, p. 123).

\section{Grading}

Faculty developers may use grades to assess learner work for various purposes. For example, grades can be used to "stimulate and encourage good work" (Davis, 2009, p. 409). Another purpose for using grades is to describe what good work is, and to help participants recognise good work and improve their learning (Davis, 2009). As stated previously, it is important to make sure that each assignment is aligned with the course goals and learning outcomes so that learners are able to make connections between assignments and learning outcomes (Kumar \& Refaei, 2013). Grades can be used to determine if learning outcomes have been achieved (Davis, 2009). However, if too much focus is placed on grades, learner's fear will increase (Frisby et al., 2014; Huba \& Freed, 2000). Therefore, participants need clear criteria for performance that can help them assess their performance in order to achieve the learning outcomes (Davis, 20009; Huba \& Freed, 2000). An excellent way to present criteria for quality performance is by creating a rubric.

The rubric is an assessment tool that explains to learners "the criteria against which their work will be judged" (Huba \& Freed, 2000, p. 155). Using a rubric for grading participant work solves the reliability issue that relates to "the subjectivity of human judgment" (Huba \& Freed, 2000). Faculty developers will judge participant work using "agreed-upon criteria" (Huba \& Freed, 2000, p. 151). A strong rubric provides detailed descriptions of the assignments as well as the levels of performance quality within participant work (Huba \& Freed, 2000). Also, by using a rubric for assignments, the faculty developer illustrates the most important indicators of learning that he or she is looking for in participant work (Driscoll \& Wood, 2007).

According to Driscoll \& Wood (2007), the use of rubrics is recommended, especially for assignments that are complex or difficult to assess. A rubric specifies what is expected from learners in order to succeed in the course (Huba \& Freed, 2000). Therefore, the current course uses a rubric of five criteria with three standards or levels of achievement (i.e., Needs Improvement, Satisfactory, and Exemplary). At the exemplary level, participant work will be of high quality. It will be well-organised, following a logical order. It will reflect a mastery of the course material, demonstrating an understanding of the topic. It will be error-free and easy 
to understand, and it will use correct APA formats. The satisfactory work will be of good quality, but missing some minor parts of the assignment. For example, the work will be accepted and labeled as satisfactory if most parts of the paper are organised but not all parts follow a logical order. The work includes minor parts that are not related to the purpose of the assignment, and a few grammar and syntax errors are present. The third and least level of achievement is the work labeled Needs Improvement. In this category there are major parts of the assignment missing; the work reflects unfamiliarity with the course material; it is difficult to follow or understand the meaning. The rubric shows the dedicated percentage of grade for each criterion. There is a comments section to the rubric designed for the faculty developer to leave his or her feedback. According to Huba and Freed (2000), "to be effective, students need feedback about how and what they're doing ... most importantly, they must learn how to use that feedback to improve performance" (p. 153). Also, opening a discussion with participants about how to use feedback to improve their performance would be very helpful early on during course time (Davis, 2009).

\section{Teaching Strategies}

In order to select appropriate instructional methods for teaching, faculty developers should focus on what participants are going to do rather than what the faculty developer is going to do (Davis, 2009). According to Bain (2004, p. 109), participants tend to learn effectively when (1) they try solving a problem; (2) the course session environment is supportive and participants have control over their learning; (3) participants are able to collaborate with others; (4) participants believe that their work will be considered fairly; (5) participants are able to try and fail, and receive feedback as they continue trying.

The strategy in teaching this course will focus on the participants as learners by providing them with opportunities to communicate their experiences, reflect on their understanding, and share their thoughts with each other. There are a variety of learner-centred teaching strategies that allow participants to be actively involved in demonstrating their learning. For example, participants can apply what they have learned through discussion and collaborative work. The faculty developer will be conducting large and small group discussion and collaborative activities at the beginning of each session meeting to discuss questions related to old and new topics. For small group activities, "in general, groups of four or five members work best" (Davis, 2009, p. 196). Asking questions is an effective strategy to prepare learners for instruction. It also creates a critical learning environment (Bain, 2004; Davis, 2009). However, the faculty developer should ask only one question at a time; he or she should ask questions that invite multiple answers; he or she should encourage participant-to-participant interaction and avoid yes-or-no questions (Davis, 2009, pp. 121-123). It also is important to praise correct answers, and use follow-up questions (Davis, 2009; Rocca, 2010). Follow-up questions encourage participants to reflect on their understanding, and to become critical thinkers (Davis, 2009). 
Lectures and presentations will be used to teach the course. Faculty developers who use lectures should emphasise important points during the lecture and facilitate participant enthusiasm for learning through their vocal and physical presence. "Everyone agrees that if you appear bored with the topic, students will quickly lose interest" (Davis, 2009, p. 151). Also, it is important to establish rapport with participants (Davis, 2009; Frisby \& Martin, 2010). For example, looking directly at participants one at a time gives them a sense that the faculty developers are speaking to each individual (Davis, 2009). Also, referring to participants by name creates a sense of community (Davis, 2009; Frisby \& Martin, 2010; Rocca, 2010). In order to remember participant names, faculty developers can use a seating chart for the session, or use name cards (Davis, 2009). Using name cards allows the faculty developers to remember participant names, and helps participants remember each other's as well.

\section{Faculty Developer's Role}

Malcolm Knowles proposed the concept of Andragogy, suggesting that adult students learn differently than other students (i.e., kids and children) (Merriam et al., 2007). According to Knowles, the most effective stimulus in the adult learning process is internal rather than external. In higher education, educators should focus on developing internal authorship, suggesting that the learner's internal voice is his or her source of authority (Alkathiri, 2019). Baxter Magolda (2004) introduced the Learning Partnerships Model to help the adult learner adapt to internal authorship. The Learning Partnerships Model describes learning as a complex process in which learners give and take knowledge based on their own perspectives and internal beliefs (Baxter Magolda, 2004). Participants become responsible for their learning and trust the faculty developer to facilitate their learning (Alkathiri, 2019; Frisby \& Martin, 2010). They are able to take ownership and see the great value in sharing their ideas (Stearns, 2013). Participants' trust is necessary for expediting the flow of information back and forth, in and out. When trust is present, participant learning is enhanced (Frisby \& Martin, 2010; Huba \& Freed, 2000). This model enhances the development of learner authorship and prepares them for future professional challenges.

Baxter Magolda (2004, p. 188) demonstrates three developmental dimensions that challenge learners to become self-authored: "knowledge is complex and socially constructed" (epistemological growth), "self is central to knowledge construction" (intrapersonal growth), and "authority is shared in the mutual construction of knowledge among peers" (interpersonal growth). In order to support the development of self-authorship, the roadmap for faculty developers is the application of the three core principles described by Baxter Magolda (2004).

First, to validate learners as knowers: faculty developers should ensure that participants know their voices are heard and that their instructor is not the ultimate authority. It is important for the faculty developer to learn about his or her learners' expectations for the course being taught (Davis, 2009). Therefore, participants will be asked to specify 2-3 goals that they hope to 
achieve. Reading the participant goals will allow faculty developers to identify learner interests and motivation for taking the course.

Second, to situate learning in the learner's own experience: faculty developers need to recognise that participants bring past experiences into the classroom. Therefore, faculty developers should develop assignments that relate to participants' prior knowledge and experiences (Davis, 2009; Huba \& Freed, 2000; Merriam et al., 2007). The acknowledgment of all participant contributions will encourage participation throughout the course sessions (Davis, 2009; Rocca, 2010). For this reason, it was stated under "Professional Expectations" that participants must demonstrate consideration of all diverse opinions during course meetings.

Third, to define learning as mutually constructing meaning, faculty developers should frame learning as something done collectively. Participants should be allowed to see the faculty developer's learning, thinking and reasoning. Therefore, participants will be offered opportunities for collaboration and discussion throughout many of the course activities. At the same time, the faculty developer will be modelling many of the characteristics taught in the way he or she interacts in course meetings.

Designing a new course is about anticipating learner needs, in this case, faculty member needs. By understanding and implementing this plan of these three principles, faculty developers will be able to engage learners most effectively, providing them with the support they need. This method will help participants make sense of new ideas and concepts as it encourages construction and reflection of knowledge based on experiences and inner needs.

Course design is an ongoing process that demands continuous examination of its impact on participants' learning (Kumar \& Refaei, 2013). Although creating a new course was a challenging task, it was a great experience. As a faculty developer and course designer, the process of recognising all the elements that relate to the course was informative. For example, the author evaluated the course from the faculty developer's point of view. What are the faculty developer's expectations? What are the appropriate teaching strategies? What assessment methods should be used? At the same time, learner perspectives were considered. What do they want to learn about? What motivates them? How can they be engaged in the learning process? Further, the scientific and academic point of view were addressed. What topics must this course cover? What literature tells us about designing an effective course? Finally, the author integrated his own knowledge, feelings, and experiences to this task. What does the author think and feel about certain elements of the task? How does the author prepare himself for this? What was missing in other courses? What good strategies were useful for participants' learning in the past? Course design is difficult but rewarding. Faculty development is about empowering faculty members to be their best, especially in teaching. This can be achieved 
International Journal of Innovation, Creativity and Change. www.ijicc.net

Volume 15, Issue 3, 2021

through the creation of a course where faculty members, as learners, are at the centre of instruction, and faculty developers, as facilitators, are supportive. 
International Journal of Innovation, Creativity and Change. www.ijicc.net

Volume 15, Issue 3, 2021

\section{REFERENCES}

Alkathiri, M. S. (2018). Using art-based techniques in faculty training programmes. In T. Chemi and X. Du (Eds.), Palgrave Studies in Business, Arts and Humanities. Artsbased methods and organizational learning (pp. 265-290). Gewerbestrasse: Palgrave Macmillan.

Alkathiri, M. S. (2019). Assessing doctoral student development of self-authorship: The epistemological, intrapersonal, and interpersonal growths. International Journal of Doctoral Studies, 14, 597-611.

Alkathiri, M. S., \& Olson, M. R. (2018). Perceived challenges facing doctoral students and perceptions of the professoriate. Educate The Journal of Doctoral Research in Education, 18(1), 2-12.

Alkathiri, M. S., \& Olson, M. R. (2019). Preparing doctoral students for the professoriate through a formal preparatory course. International Journal of Doctoral Studies, 14, 33 67.

Bain, K. (2004). What the best college teachers do. Cambridge, MA: Harvard Press.

Baxter Magolda, M. B. (2004). Learning partnerships model: A framework for promoting selfauthorship. In M. B. Baxter Magolda \& P. M. King (Eds.), Learning partnerships: Theory and models of practice to educate for self-authorship (pp. 37-62). Sterling, VA: Stylus.

Bresciani, M. J. (2006). Outcomes-based academic and co-curricular program review: A compilation of institutional good practices. Sterling, VA: Stylus.

Dancer, D., \& Kamvounias, P. (2005). Student involvement in assessment: A project designed to assess class participation fairly and reliably. Assessment \& Evaluation in Higher Education, 30, 445-454.

Davis, B. (2009). Tools for teaching. San Francisco: Jossey-Bass.

Deanship of Academic Development (2019). Strategic plan 2019-2024. Saudi Arabia: Imam Abdulrahman bin Faisal University. Retrieved October 10, 2020, from https://www.iau.edu.sa/sites/default/files/content-box/dad_sp_2019-2024_0.pdf

Driscoll, A., \& Wood, S. (2007). Developing outcomes-based assessment for learner-centered education. Sterling, VA: Sylus Publishing, LLC.

Frisby, B. N., Berger, B., Burchett, M., Herovic, E., \& Strawser, M. G. (2014). Participation apprehensive students: The influence of face support and instructor-student rapport on classroom participation. Communication Education, 63(2), 105-123. 
International Journal of Innovation, Creativity and Change. www.ijicc.net

Volume 15, Issue 3, 2021

Frisby, B. R., \& Martin, M. M. (2010). Instructor-student and student-student rapport in the classroom. Communication Education, 59(2), 146-164.

Houser, M. L., \& Frymier, A. B. (2009). The role of student characteristics and teacher behaviors in students' learner empowerment. Communication Education, 58(1), 35-53.

Huba, M. E., \& Freed, J. E. (2000). Learner-centered assessment on college campuses: Shifting the focus from teaching to learning. Needham Heights, MA: Allyn \& Bacon.

Kumar, R., \& Refaei, B. (2013). Designing a problem-based learning intermediate composition course. College Teaching, 61(2), 67-73.

Maki, P. L. (2010). Assessing for learning: Building a sustainable commitment across the institution. Sterling, VA: Stylus.

Merriam, S. B., Caffarella, R. S., \& Baumgartner, L. M. (2007). Learning in adulthood: A comprehensive guide (3rd ed.). San Francisco: Jossey Bass.

Rocca, K. A. (2010). Student participation in the college classroom: An extended multidisciplinary literature review. Communication Education, 59(2), 185-213.

Scouller, K. (1998). The influence of assessment method on students' learning approached: Multiple choice question examination versus assignment essay. Higher Education, 35, 435-472.

Stearns, S. A. (2013) Motivating students to offer their best: Evidence based effective course design. College Teaching, 61(4), 127-130.

Wall, M. L. (2013). Using balanced learning course design to reduce resistance to diversity curricula. Enhancing Learning in the Social Sciences, 5(2), 45-54. 